Vol. 18 (2009): 16-26.

\title{
Animal performance and carcass characteristics of growing Hereford bulls under insulated, uninsulated and outdoor housing conditions in Northern Finland
}

\author{
Arto Huuskonen ${ }^{1 *}$, Leena Tuomisto ${ }^{1}$, Erkki Joki-Tokola ${ }^{1}$, Risto Kauppinen ${ }^{2}$ \\ ${ }^{1}$ MTT Agrifood Research Finland, Animal Production Research, FI-92400 Ruukki, Finland \\ *email: arto.huuskonen@mtt.fi \\ ${ }^{2}$ Savonia University of Applied Science, PO Box 72, FI-74101 Iisalmi, Finland
}

\begin{abstract}
The objective of the present study was to compare the performance of Hereford bulls in an insulated tie-stall, an uninsulated barn and a forest paddock in Northern Finland (Ruukki: $64^{\circ} 44^{\prime} \mathrm{N}, 25^{\circ} 15^{\prime} \mathrm{E}$ ). In November 1999, thirty Hereford bulls (age 6.8 \pm 0.5 (mean \pm SD) months; live weight (LW) $285 \pm 35 \mathrm{~kg}$ ) were divided into six groups of five animals according to their $\mathrm{LW}$ and the groups were randomly allotted to one of three treatments: tie-stall in an insulated barn (IB bulls, ten animals in individual stalls), pen in an uninsulated barn (UB bulls, 5 animals per pen, two pens) and forest paddock (PAD bulls, 5 animals per paddock, two paddocks). The experiment ended in October 2000, when the bulls were $18.3 \pm 0.5$ months of age and $772 \pm 51$ $\mathrm{kg}$ LW. During the entire experiment the live weight gain (LWG) of the UB bulls was $7 \%$ higher than that of the IB bulls (1436 vs. $1339 \mathrm{~g} \mathrm{~d}^{-1}, p<0.05$ ) and there was a tendency that the LWG of the PAD bulls was $6 \%$ higher than that of the IB bulls ( 1414 vs. $1339 \mathrm{~g} \mathrm{~d}^{-1}, p<0.1$ ). Carcass gain of the UB bulls was $8 \%$ higher than that of the IB bulls ( 812 vs. $751 \mathrm{~g} \mathrm{~d}^{-1}, p<0.05$ ). The carcass conformation score of the PAD bulls was $23 \%$ higher than that of the IB bulls ( 7.6 vs. 6.2 EUROP conformation, $p<0.05$ ), but there were no significant effects of treatments on the dressing proportion or carcass fat score. The dry matter and energy intakes $\left(\mathrm{g} / \mathrm{kg} \mathrm{W}^{0.75}\right.$ and $\left.\mathrm{MJ} / \mathrm{kg} \mathrm{W}^{0.75}\right)$ of the IB bulls were significantly lower than those of the UB and PAD bulls during both feeding periods (winter: from 2 November 1999 to 25 April 2000, summer: from 26 April 2000 to 16 October 2000) and during the entire experiment. According to this study, finishing beef bulls can be overwintered outdoors in Northern Finland without warm housing facilities. Compared with the tie-stall system, the energy expenditure of walking and other exercise increases in outdoor housing systems, which also means increasing energy intake.
\end{abstract}

Key-words: Beef production, bulls, housing, animal performance, carcass characteristics, feed intake 


\section{AGRICULTURAL AND FOOD SCIENCE}

Vol. 18 (2009): 16-26.

\section{Introduction}

Rising housing costs have created a demand for inexpensive winter housing systems for beef cattle in Finland (e.g. Manninen et al. 2008), and one method of reducing these costs is to overwinter growing cattle outdoors. For example, in Taivalko-

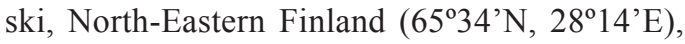
400-600 growing animals are every year raised on very extensive forested land ( 0.5 animal unit ha $\left.{ }^{-1}\right)$ (Uusi-Kämppä et al. 2007). Hands-on experience in Taivalkoski (Lehtiniemi et al. 2001) indicates that young cattle perform quite well outdoors during wintertime, if the facilities are equipped with a rain shelter to cover a dry resting area with sufficient bedding material available to keep the animals dry and clean. However, there is also a lot of public concern for the performance and welfare of these outdoor-housed animals in northern Finland.

In general, growing cattle are very cold-hardy and have very low critical temperatures (Webster 1974). Accordingly, in outdoor or uninsulated conditions, growing cattle often exhibit good performance (e.g. Mossberg et al. 1992, 1993, Redbo et al. 1996, Manninen et al. 2007), but opposite results have also been reported, e.g. by Delfino and Mathison (1991). Regarding outdoor housing studies conducted in North America, growth-promotant implants, which are forbidden in Finland, are often used in beef cattle experiments (e.g. Birkelo and Lounsbery 1992), making the results of these studies less useful for the Finnish beef sector. In Finland, the effects of uninsulated housing have been studied with dairy calves (Kauppinen 2000, Hänninen et al. 2003, Hepola et al. 2006), beef heifers (Manninen et al. 2007) and suckler cows (Manninen et al. 2005, 2008). However, most of these Finnish experiments have been conducted in Southern Finland (Helsinki 60 $10^{\circ} \mathrm{N}, 24^{\circ} 56^{\prime} \mathrm{E}$ : Hänninen et al. 2003, Hepola et al. 2006) or Eastern Finland (Tohmajärvi $62^{\circ} 20^{\prime} \mathrm{N}, 30^{\circ} 15^{\prime} \mathrm{E}$ : Manninen et al. 2005, 2007, 2008), and there are differences in climatic conditions (outdoor temperatures, rainfall, wind) in Northern Finland compared to other places mentioned. There is only little knowledge of the effect of different housing environments on the performance of growing bulls under climatic conditions like in Northern Finland. Therefore, the objective of the present study was to compare the performance of Hereford bulls housed in an insulated tie-stall, in an uninsulated barn and in a forest paddock in Northern Finland.

\section{Materials and methods}

\section{Animals, experimental procedure and housing environments}

The experiment was conducted at the North Ostrobothnia Research Station of MTT Agrifood Research Finland in Ruukki ( $\left.64^{\circ} 44^{\prime} \mathrm{N}, 25^{\circ} 15^{\prime} \mathrm{E}\right)$, from November 1999 to October 2000, and comprised 30 Hereford bulls. The bulls were born in spring 1999 at the Tohmajärvi Suckler Cow Barn of MTT Agrifood Research Finland (62 $\left.20^{\prime} \mathrm{N}, 30^{\circ} 15^{\prime} \mathrm{E}\right)$ and spent their first summer with their dams on pasture. In autumn 1999, the bulls were weaned and transferred to the North Ostrobothnia Research Station. The experimental procedures were evaluated and approved by the Animal Care and Use Committee of MTT Agrifood Research Finland. In November 1999 , the bulls (age $6.8 \pm 0.5$ (mean \pm SD) months; live weight (LW) $285 \pm 35 \mathrm{~kg}$ ) were divided into six groups of five animals according to their LW and the groups were randomly allotted to one of three treatments: tie-stall in an insulated barn (IB bulls, ten animals in individual stalls), uninsulated barn (UB bulls, 5 animals/pen, two pens) and forest paddock (PAD bulls, 5 animals/paddock, two paddocks). All the bulls were dewormed (Eprinex, eprinomectin $5 \mathrm{mg} \mathrm{ml}^{-1}, 0.5 \mathrm{mg}(\mathrm{LW} \mathrm{kg})^{-1}$, produced by Merial, Lyon, France) at the start of the experiment. There were not diseases or veterinary treatments during the experimental period.

The IB bulls were placed in an insulated barn in adjacent tie-stalls. The width of the stalls was $70-90 \mathrm{~cm}$ for the first four months and $113 \mathrm{~cm}$ until the end of the experiment. The bulls were tied with a collar around the neck and with a chain of $50 \mathrm{~cm}$, 


\section{AGRICULTURAL AND FOOD SCIENCE}

\section{Huuskonen, A. et al. Performance of growing bulls under different housing conditions}

which was attached to a horizontal bar $40-55 \mathrm{~cm}$ above the floor. The floor surface was solid concrete under the forelegs and metal grids under the hind legs. No bedding was used on the floor. All bulls had their own water bowls.

The UB bulls were placed in an uninsulated barn into adjacent pens $\left(4 \times 8 \mathrm{~m}, 6.4 \mathrm{~m}^{2}\right.$ per bull $)$. The uninsulated barn was covered with a roof and it had solid wooden walls on all sides except for the front side that was left open. The rear half of the pen area was a straw-bedded lying area and the fore half was a feeding area with a solid concrete floor. A feeding trough was situated on the front side of the pen, and there was $0.8 \mathrm{~m}$ of feeding space per bull at the feeding trough. There was one heated water bowl between the pens offering water for all ten pen bulls. The concrete feeding area was cleaned three times a week and the bedded lying area was cleaned monthly. Barley straw was added to the bedded lying area three times a week.

The PAD bulls were placed in two adjacent forest paddocks $\left(50 \times 100 \mathrm{~m}, 1000 \mathrm{~m}^{2}\right.$ per bull $)$ that were built up in young forest. The vegetation of the paddock area consisted mostly of young conifer trees mixed with some birches. The ground was covered with twigs and grass. The vegetation and

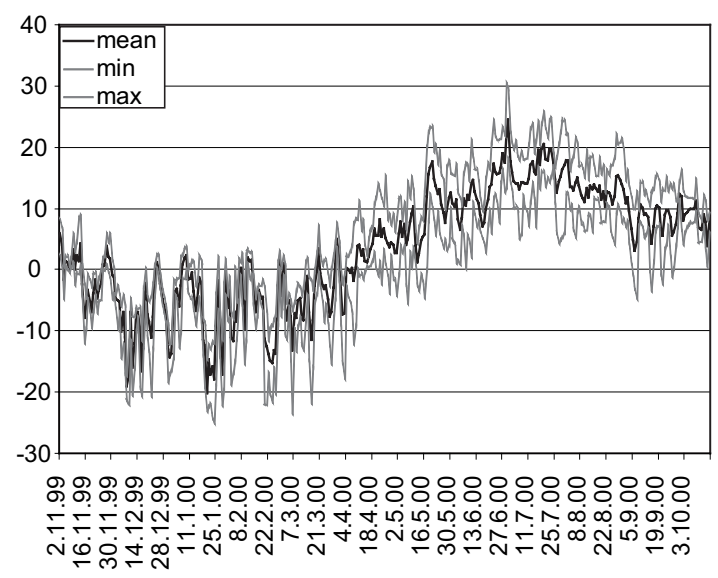

Fig. 1. Mean, minimum and maximum daily outdoor temperatures $\left({ }^{\circ} \mathrm{C}\right)$ during the experiment. soil texture of the paddock area are fully described by Uusi-Kämppä et al. (2007). A wooden fence separated the paddocks from each other. The other three sides of the paddocks were fenced with an electric fence. Between the two paddocks there was a simple, roofed, three-walled shed $(8 \times 4 \mathrm{~m})$ available for the bulls. The floor of this shed was deep straw-bedded. In front of the shed was a feeding area $(8 \times 4 \mathrm{~m})$ with a solid concrete floor. The shed as well as the feeding area were split in two with wooden walls so that each group of paddock bulls had access to a shed area of $4 \times 4 \mathrm{~m}$ and a feeding area of $4 \times 4 \mathrm{~m}$. A feeding trough was situated in front of the feeding area with $1.0 \mathrm{~m}$ of feeding space per bull. There was one heated water bowl in the feeding area offering water for all the ten paddock bulls. The concrete-floored feeding area was cleaned once a week. Barley straw was added to the bedded lying area three times a week in winter and once a week during the summer.

Outdoor temperature (Fig. 1) and daily rainfall (Fig. 2) were measured at the experimental site during the experiment. The air temperature of the insulated barn fluctuated between 5 and $15^{\circ} \mathrm{C}$ in winter (November 1999-April 2000) and between 15 and $25^{\circ} \mathrm{C}$ in summer (May 2000-October 2000).

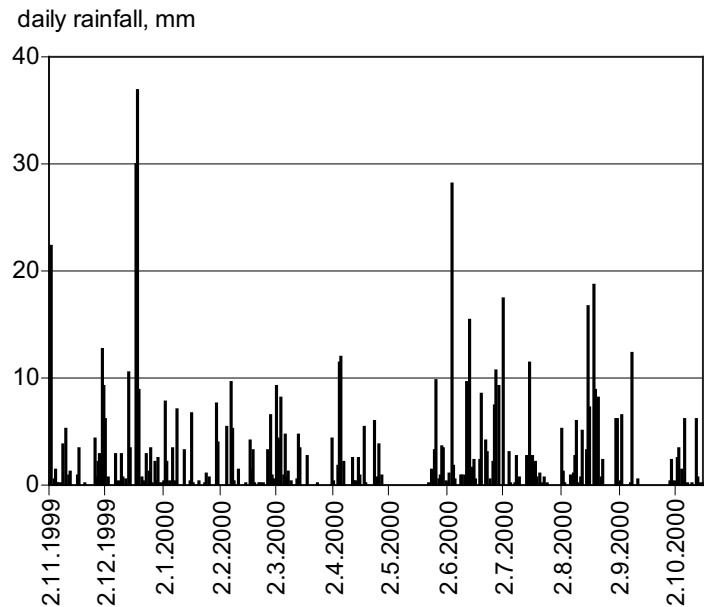

Fig. 2. Daily rainfall (mm) during the experiment. 


\section{AGRICULTURAL AND FOOD SCIENCE}

Vol. 18 (2009): 16-26.

\section{Diet and sample analyses}

All bulls were fed ad libitum a total mixed ration (TMR) twice a day (approximately at 0700 and 1900). Refused feed was collected and measured daily at 0700 . The dry matter (DM) of the TMR was composed of $500 \mathrm{~g} \mathrm{~kg}^{-1} \mathrm{DM}$ of grass silage and 500 $\mathrm{g} \mathrm{kg}^{-1} \mathrm{DM}$ of rolled barley. The daily ration also included a mineral mixture (Feedmix Ltd., Finland: Tähkä Apekivennäinen: Ca 235, P 8, Na 74, Mg 40 $\mathrm{g} \mathrm{kg}^{-1}$ ) $150 \mathrm{~g}$ animal $^{-1}$. A vitamin mixture (Suomen Rehu, Finland: Xylitol ADE-Vita: A 2,000,000 IU $\mathrm{kg}^{-1}, \mathrm{D}_{3} 400,000 \mathrm{IU} \mathrm{kg}^{-1}$, E DL- $\alpha$-tocopheryl acetate $1,000 \mathrm{mg} \mathrm{kg}^{-1}$, E DL- $\alpha$-tocopheryl $900 \mathrm{mg} \mathrm{kg}^{-1}$, Se $10 \mathrm{mg} \mathrm{kg}^{-1}$ ) was given at $50 \mathrm{~g}$ animal $^{-1}$ weekly. The grass silage was primary growth from a timothy (Phleum pratense) and meadow fescue (Festuca pratensis) sward and ensiled in bunker silos with a formic acid-based additive (AIV-2 Plus: $760 \mathrm{~g}$ formic acid $\mathrm{kg}^{-1}, 55 \mathrm{~g}$ ammoniumformiate $\mathrm{kg}^{-1}$, Kemira Ltd., Oulu, Finland) applied at a rate of $5 \mathrm{~L}$ per tonne of fresh grass.

Grass silage was analysed for DM (determined at $105^{\circ} \mathrm{C}$ for $20 \mathrm{~h}$ ) at the beginning of the experiment and twice a week thereafter for preparation of TMR. Silage sub-samples for chemical analyses were taken twice a week, pooled over periods of four weeks and stored at $-20^{\circ} \mathrm{C}$. Thawed samples were analysed for DM, ash, crude protein (CP), neutral detergent fibre (NDF), silage fermentation quality $(\mathrm{pH}$, water-soluble carbohydrates, lactic and formic acids, volatile fatty acids, soluble and ammonia $\mathrm{N}$ content of $\mathrm{N}$ ) and digestible organic matter (DOM) in DM (D value). Concentrate subsamples were collected weekly, pooled over periods of four weeks and analysed for DM, ash, CP and NDF. The analyses were made and the metabolizable energy (ME) value of the feeds was calculated as described by Huuskonen et al. (2007a,b). The digestibility coefficients of barley were taken from Finnish feed tables (MTT 2006). The supply of amino acids absorbed from the small intestine (AAT) was calculated according to Finnish feed tables (MTT 2006).

\section{Measurements}

The animals were weighed on two consecutive days at the beginning of the experiment. There after the animals were weighed every 28 days and before slaughter on two consecutive days. The live weight gain (LWG) was calculated as the difference between the means of initial and final weights. The estimated rate of carcass gain was calculated by assuming an initial carcass weight of 0.50 of initial LW, which was used also in studies by Root and Huhtanen (1998) and Huuskonen et al. (2008). After slaughter in a commercial meat plant, carcasses were weighed hot. Cold carcass weight was estimated as 0.98 of hot carcass weight. Dressing proportions were calculated from the ratio of cold carcass weight to final live weight. For conformation, the development of carcass profiles, in particular the essential parts (round, back, shoulder), was taken into consideration according to the EUROP classification (E: excellent, U: very good, R: good, O: fair, $\mathrm{P}$ : poor), and for fat cover degree the amount of fat on the outside of the carcass and in the thoracic cavity was taken into account using a classification range from 1 to 5 (1: low, 2: slight, 3: average, 4: high, 5: very high). Each level of the conformation scale was subdivided into 3 sub-classes (i.e. $\mathrm{O}+, \mathrm{O}$, $\mathrm{O}-$ ) on a transformed scale ranging from 1 to 15 , with 15 as the best conformation (Commission of the European Communities 1982).

The experiment was divided into two subexperimental periods: winter (from 2 November 1999 to 25 April 2000) and summer (from 26 April 2000 to 16 October 2000). The LWG and feed DM intakes of the bulls are also presented separately for these sub-experimental periods.

\section{Statistical analysis}

Daily feed intake was measured penwise (intake of five bulls) in the uninsulated barn and in the forest paddocks. In the insulated barn in tiestalls the bulls were individually fed. However, a group of five bulls was used as an experimental unit also in the insulated barn and thus the mean 
Huuskonen, A. et al. Performance of growing bulls under different housing conditions

values for each group were calculated. There were two experimental units per housing environment (in total 10 bulls for each housing environment). Feed and energy intake data was analysed using one-way analysis of variance.

The rest of response variables were measured individually and analysed using the following statistical model:

$Y_{i j k}=\mu+\beta_{i}+\theta_{j(i)}+\varepsilon_{i j k}$

where $i=1,2,3$ (housing environment), $j=1,2,3, \ldots, 6$ (group of five bulls). $Y_{i j k}$ is observation from the $k$ th animal in the $i$ th housing environment and the $j$ th group in housing environment. $\mu$ is the general mean and $\beta_{i}$ is the effect of the $i$ th housing environment. Furthermore, $\theta_{j(i)}$ is the effect of group and it was used as an error term when housing environments were compared using the a priori -test (Dunnett's test). IB was used as a control environment in Dun- nett's test. Finally, $\varepsilon_{i j k}$ is the residual error. Normality of residuals was checked for each analysis using graphical methods: box-plot and scatter plot of residuals and fitted values. All statistical analyses were performed using the SAS (Version 8.2) general linear models procedure (SAS Institute Inc., Cary, NC, USA).

\section{Results}

The content of DM, OM, CP, NDF and calculated contents of ME and AAT of the grass silage, barley and TMR are given in Table 1. The digestibility level of the silage (700 $\mathrm{g} \mathrm{DOM} / \mathrm{kg} \mathrm{DM}$ ) was high and the preservation quality of the silage, as indicated by $\mathrm{pH}$ value and contents of ammonia- $\mathrm{N}$ and fatty acids, was good (Table 1).

Table 1. Chemical composition and feeding values of barley, grass silage and total mixed ration $(\mathrm{TMR})\left(\mathrm{mean} \pm \mathrm{SD} \mathrm{a}^{\mathrm{a}}\right)$.

\begin{tabular}{lccc}
\hline & Barley & Grass silage & TMR \\
\hline Number of samples & 12 & 12 & 12 \\
Dry matter (DM), $\mathrm{g} \mathrm{kg}^{-1}$ feed & $921 \pm 3.8$ & $284 \pm 108.2$ & $434 \pm 93.2$ \\
Organic matter (OM), $\mathrm{g} \mathrm{kg}^{-1} \mathrm{DM}$ & $976 \pm 8.6$ & $918 \pm 15.9$ & $953 \pm 13.1$ \\
Crude protein, $\mathrm{g} \mathrm{kg}^{-1} \mathrm{DM}$ & $123 \pm 10.4$ & $168 \pm 13.1$ & $146 \pm 12.5$ \\
Neutral detergent fibre, $\mathrm{g} \mathrm{kg}^{-1} \mathrm{DM}$ & $198 \pm 13.2$ & $542 \pm 17.9$ & $350 \pm 16.1$ \\
Digestible OM in DM, $\mathrm{g} \mathrm{kg}^{-1} \mathrm{DM}$ & - & $700 \pm 20.3$ & - \\
Metabolizable energy, $\mathrm{MJ} \mathrm{kg}^{-1} \mathrm{DM}$ & $13.3 \pm 0.1$ & $11.1 \pm 0.4$ & $12.2 \pm 0.3$ \\
$\mathrm{AAT}^{\mathrm{b}}, \mathrm{g} \mathrm{kg}^{-1} \mathrm{DM}$ & $104 \pm 3.4$ & $85 \pm 3.6$ & $94 \pm 3.5$ \\
Fermentation quality of silage & & & \\
pH & & $4.1 \pm 0.3$ & \\
$\quad$ Volatile fatty acids, $\mathrm{g} \mathrm{kg}^{-1} \mathrm{DM}$ & & $10.3 \pm 6.5$ & \\
Lactic + formic acid, g kg-1 DM & & $44 \pm 14.8$ & \\
Water soluble carbohydrates, $\mathrm{g} \mathrm{kg}$ & \\
$\quad$ In total nitrogen, $\mathrm{g} \mathrm{kg}^{-1}$ & & $35 \pm 20.8$ & \\
$\quad$ Ammonia N & & & \\
$\quad$ Soluble N & & $60 \pm 9.2$ & \\
\hline
\end{tabular}

\footnotetext{
${ }^{\text {a }}$ Standard deviation.

${ }^{\mathrm{b}}$ Amino acids absorbed from small intestine (MTT 2006).
} 
Vol. 18 (2009): 16-26.

The experiment ended in October 2000, when the bulls were $18.3 \pm 0.5$ months of age and $772 \pm 51$ $\mathrm{kg} \mathrm{LW}$. The mean carcass weight was $414 \mathrm{~kg}$, and there were no significant differences between the treatments (Table 2). During the winter period the LWG of the UB bulls was $11.6 \%$ higher than that of the IB bulls (1466 vs. $1314 \mathrm{~g} \mathrm{~d}^{-1}, p<0.05$ ) and during the summer period there was a tendency that the LWG of the PAD bulls was higher than that of the IB bulls (1472 vs. $1364 \mathrm{~g} \mathrm{~d}^{-1}, p<0.1$ ). Throughout the experiment the LWG of the UB bulls was 7\% higher than that of the IB bulls (1436 vs. $\left.1339 \mathrm{~g} \mathrm{~d}^{-1}, p<0.05\right)$ and there was a tendency that the LWG of the PAD bulls was $6 \%$ higher than that of the IB bulls (1414 vs. $\left.1339 \mathrm{~g} \mathrm{~d}^{-1}, p<0.1\right)$. The carcass gain of the bulls was $8 \%$ higher in the UB than in the IB treatment ( $812 \mathrm{vs} .751 \mathrm{~g} \mathrm{~d}^{-1}, p<0.05$ ). The dressing proportion of the IB bulls tended to be higher than that of the PAD bulls (538 vs. $529 \mathrm{~g}$ $\left.\mathrm{kg}^{-1}, p<0.1\right)$, but there were no differences between the IB and UB bulls in the dressing proportion. The carcass conformation score of the PAD bulls was $23 \%$ higher than that of the IB bulls $(p<0.05)$, but there were no significant effects of the treatments on the carcass fat score (Table 2).

Table 2. Growth, carcass characteristics and feed intake of bulls housed in an insulated barn (IB), uninsulated barn (UB) and forest paddock (PAD).

\begin{tabular}{|c|c|c|c|c|c|c|}
\hline & & & & & & \\
\hline & IB & UB & PAD & SEM $^{\mathrm{b}}$ & $\mathrm{C} 1$ & $\mathrm{C} 2$ \\
\hline Initial live weight, $\mathrm{kg}$ & 285 & 284 & 287 & 11.4 & 0.93 & 0.92 \\
\hline Final live weight, $\mathrm{kg}$ & 753 & 785 & 780 & 15.9 & 0.14 & 0.21 \\
\hline Carcass weight, $\mathrm{kg}$ & 405 & 425 & 412 & 8.6 & 0.09 & 0.52 \\
\hline Live weight gain (LWG), $\mathrm{g} \mathrm{d}^{-1}$ & & & & & & \\
\hline Winter (2.11.1999-25.4.2000) & 1314 & 1466 & 1356 & 40.9 & 0.01 & 0.46 \\
\hline Summer (26.4.2000-16.10.2000) & 1364 & 1406 & 1472 & 46.0 & 0.51 & 0.09 \\
\hline From start to slaughter & 1339 & 1436 & 1414 & 29.9 & 0.02 & 0.08 \\
\hline Carcass gain, $\mathrm{g} \mathrm{d}^{-1}$ & 751 & 812 & 771 & 18.0 & 0.02 & 0.42 \\
\hline Dressing proportion, $\mathrm{g} \mathrm{kg}^{-1}$ & 538 & 542 & 529 & 3.8 & 0.44 & 0.08 \\
\hline EUROP conformation $^{\mathrm{c}}$ & 6.2 & 6.9 & 7.6 & 0.49 & 0.28 & 0.04 \\
\hline EUROP fat classification ${ }^{\mathrm{d}}$ & 4.4 & 4.4 & 4.5 & 0.18 & 0.95 & 0.74 \\
\hline Dry matter intake, $\mathrm{g}\left(\mathrm{kg} \mathrm{W}^{0.75}\right)^{-1}$ & & & & & & \\
\hline Winter (2.11.1999-25.4.2000) & 83.2 & 87.4 & 87.2 & 0.344 & 0.003 & 0.004 \\
\hline Summer (26.4.2000-16.10.2000) & 78.6 & 84.8 & 84.1 & 1.50 & 0.004 & 0.01 \\
\hline From start to slaughter & 79.9 & 85.7 & 84.4 & 1.55 & 0.009 & 0.04 \\
\hline Energy intake, MJ ME $\left(\mathrm{kg} \mathrm{W}^{0.75}\right)^{-1}$ & & & & & & \\
\hline Winter (2.11.1999-25.4.2000) & 1.02 & 1.07 & 1.07 & 0.004 & 0.003 & 0.004 \\
\hline Summer (26.4.2000-16.10.2000) & 0.96 & 1.03 & 1.02 & 0.019 & 0.004 & 0.01 \\
\hline From start to slaughter & 0.98 & 1.05 & 1.03 & 0.019 & 0.01 & 0.04 \\
\hline Feed conversion, $\mathrm{MJ} \mathrm{kg}^{-1} \mathrm{LWG}$ & & & & & & \\
\hline Winter (2.11.1999-25.4.2000) & 70.0 & 67.0 & 71.5 & 1.44 & 0.15 & 0.45 \\
\hline Summer (26.4.2000-16.10.2000) & 90.6 & 96.2 & 90.1 & 1.08 & 0.04 & 0.79 \\
\hline From start to slaughter & 79.6 & 81.1 & 80.9 & 1.42 & 0.46 & 0.52 \\
\hline
\end{tabular}

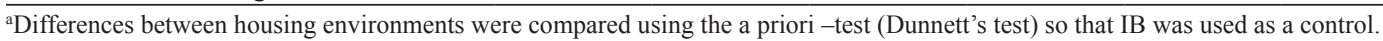

C1: IB vs. UB; C2: IB vs. PAD.

${ }^{\mathrm{b}}$ Standard error of mean.

'EUROP conformation: (1=poorest, 15=excellent).

${ }^{\mathrm{d}}$ EUROP fat cover: (1=leanest, $5=$ fattest $)$. 


\section{AGRICULTURAL AND FOOD SCIENCE}

\section{Huuskonen, A. et al. Performance of growing bulls under different housing conditions}

Dry matter and energy intakes $\left(\mathrm{g} / \mathrm{kg} \mathrm{W}^{0.75}\right.$ and $\mathrm{MJ} / \mathrm{kg} \mathrm{W}^{0.75}$ ) of the IB bulls were significantly lower than those of the UB and PAD bulls during all feeding periods (Table 2). The feed conversion rate $\left(\mathrm{MJ} / \mathrm{kg}^{-1} \mathrm{LWG}\right)$ of the IB bulls was significantly better than that of the UB bulls during the summer period $(p<0.05)$. During the winter period and throughout the experiment there were no significant differences in the feed conversion rates between the treatments.

\section{Discussion}

In the present experiment we investigated the effects of year-round outdoor housing (uninsulated barn or forested paddock) on the performance of growing bulls compared to the bulls housed in the insulated barn in the tie-stalls. The tie-stall barn was chosen for control housing environment because in Northern Finland farms, in which bulls are raised on forested land all the year round, generally have old fashion barns equipped with tie-stalls.

In the present study the average LWG of the bulls was higher in the uninsulated environment than in the insulated tie-stall. Many papers have been published describing the effect of uninsulated housing environments on the performance of growing animals. In some cases, uninsulated conditions or absence of shelters have affected animal performance negatively (e.g. Harmsen and Smits 1981, Birkelo et al. 1991, Delfino and Mathison 1991, Kubisch et al. 1991). On the other hand, many authors (e.g. Rintelen and Koller 1966, Redbo et al. 1996, Mossberg et al. 1992, 1993) have reported no negative effects of uninsulated housing on animal health or LWG. In these earlier studies there has been considerable variation in climatic conditions, feeding regimes, acclimatisation time and housing facilities, such as protection provided by shelters or windbreaks and use of bedding. These differences are probably at least partially responsible for the variable results. In regard to the young calves, due to their large surface area to body mass ratio and still undeveloped nervous and muscular systems, they may be more sensitive to cold than adults (Kauppinen 2000), and the results are partially conflicting (e.g. Rawson et al. 1989, Kauppinen 2000, Hänninen et al. 2003). Uninsulated buildings imply not only lower but also more variable temperatures than insulated buildings, and long-term housing in cold and variable temperatures is not free from problems. It can be concluded from the earlier experiments that the effects of outdoor conditions on the performance of growing cattle differ largely depending on the housing circumstances, the age of the animals, the length of the cold period as well as the average or minimum temperatures achieved during the cold periods.

Cold weather reduces feed conversion and, if severe, it can also suppress growth (LeRoy-Hahn 1981). Christopherson (1976) observed that a cold ambient temperature reduced the digestibility of feed in calves and steers and to offset the lowered digestibility, the animals accordingly consumed more feed to achieve a similar digestible energy intake. Westra and Christopherson (1976) assumed that the effect of cold ambient temperature on digestibility is likely to be due to a change in the passage rate of digesta through the alimentary tract, rather than to the direct effect of cold temperature on digestion. However, animals choose food which gives the best net energy return and the energy content of food usually meets well the animal's requirements if food is available ad libitum (Fraser and Broom 1990). Studies in Canada (Hironaka and Peters 1969, Lister et al. 1972) indicate that the maintenance energy requirements for overwintering beef cows increase by 30 to $70 \%$ due to adverse climatic conditions. The suckler cow performance results in Finland (Manninen et al. 2008) do not support these earlier studies, probably mainly due to the differences in climatic conditions between Canada and Finland where, in spite of cold days, the winter conditions are milder without harsh winds (Manninen et al. 2008). Similarly, in the present study the treatment differences in the DM and energy intakes were equal or even higher during the summer than during the winter periods. This indicates that environmental conditions were not a major reason for increasing intakes in uninsulated housing environments compared to the insu- 


\section{AGRICULTURAL AND FOOD SCIENCE}

Vol. 18 (2009): 16-26.

lated tie-stall. Probably the energy expenditure of walking and other exercise was the most important reason for increasing intakes.

The energy cost of walking and working in catthe has been extensively investigated (e.g. Lawrence and Stibbards 1990, Dijkman and Lawrence 1997). According to Dijkman and Lawrence (1997), the energy cost of moving $1 \mathrm{~kg}$ body weight $1 \mathrm{~m}$ forward was $1.47 \mathrm{~J} \mathrm{~m}^{-1} \mathrm{~kg}^{-1}$ for the Bos indicus cattle on smooth ground, and Lawrence and Stibbards (1990) reported an average energy expenditure of $2.09 \mathrm{~J} \mathrm{~m}^{-1} \mathrm{~kg}^{-1}$ for cattle (Bos indicus and Bos taurus) on treadmills. Supposing that the energy expenditure for walking would be $2.0 \mathrm{~J} \mathrm{~m}^{-1} \mathrm{~kg}^{-1}$, a $500-\mathrm{kg}$ bull travelling a distance of $2 \mathrm{~km}$ in the course of $24 \mathrm{~h}$ would thus expend $500 \times 2000 \times 2.0 \mathrm{~J}=2.0$ MJ. Although we did not have the possibility of measuring distances that the bulls travelled daily, it is obvious that the energy expenditure in the uninsulated environment was clearly higher than that in the tie-stall. The behavioural study (Tuomisto et al. 2008) showed that except for walking, bulls housed in uninsulated environments used time for other energy-demanding functions such as butting which was not possible for the animals in the tie-stall. In addition, it is possible that a small part of feed that was given to the UB and PAD bulls was wasted and not consumed since the feeding rack used outdoors was not optimal and it was more difficult to recover and weigh residues outdoors than in the IB. Our results indicate that the environmental conditions in Northern Finland do not necessarily increase the feed or energy intake of growing beef bulls, but the energy expenditure of walking and other exercise increase clearly in outdoor housing compared with the tie-stall. Also Mossberg et al. $(1992,1993)$ reported that there was no significant difference in feed intake between bulls housed in insulated (fully slatted concrete floor pens) and uninsulated (partly straw-bedded pens with a concrete passage along the trough) buildings at a latitude around $58^{\circ} \mathrm{N}$ in South-West Sweden. The present results also support our preliminary results with Ayrshire bulls in Northern Finland (Tuomisto et al. 2009).

The difference in exercise between the treatments might explain why the carcass conformation of the PAD bulls was higher than that of the IB bulls in the present study. The theory that exercise can explain the differences in carcass composition is supported by Levy et al. (1970) and Mossberg et al. (1992). In the present experiment there were no treatment differences in carcass fat score, but in our earlier experiment with Ayrshire bulls the carcass fat scores of the UB and PAD bulls were lower than those of the IB bulls (Tuomisto et al. 2009). Also Mossberg et al. (1992) reported that bulls in an uninsulated building had less fat in the carcasses than in an insulated building. Mossberg et al. (1992) concluded that animals in uninsulated buildings had a higher energy requirement for maintenance and activity than those housed inside on slatted floors and that the main reason for this was probably the difference between buildings in area per animal and pen design. The most important environmental factors influencing maintenance and activity requirement in the trial of Mossberg et al. (1992) were concluded to be pen design and area per animal. The animals in the uninsulated building were more active than those in the insulated building, probably because of a greater pen area and less slippery flooring. The reason why there were no treatment differences in carcass fat score in the present experiment was probably the high carcass weight of the Hereford-breed bulls. Because of the high carcass weight (414 kg, on average) the carcass fat score was very high in all treatments (4.4 EUROP fat classification, on average). It is well established that the measures of fatness increase with increasing carcass weight (Keane et al. 2006, Hessle et al. 2007).

In conclusion, according to our study, finishing bulls can be overwintered outdoors in Northern Finland without warm housing facilities. This does, however, require that the facilities provided for the bulls are at least equal to those of the present experiment. The energy expenditure of walking and other exercise increase in outdoor housing systems compared with the tie-stall system, which means also increasing energy intake in outdoor-housed animals.

Acknowledgements. Financial support from the Employment and Economic Development Centre for Northern Ostrobothnia and Juliana von Wendt's Fund is gratefully 


\section{AGRICULTURAL AND FOOD SCIENCE}

\section{Huuskonen, A. et al. Performance of growing bulls under different housing conditions}

acknowledged. The authors would like to thank Mr. Lauri Jauhiainen for advice on statistical analyses. The authors wish to express their gratitude also to Mr. Matti Huumonen and his personnel for technical assistance and excellent care of the experimental animals. The personnel at Animal Production Research in Jokioinen is thanked for the laboratory analyses.

\section{References}

Birkelo, C.P., Johnson, D.E. \& Phetteplace, H.P. 1991. Maintenance requirements of beef cattle as affected by season on different planes of nutrition. Journal of Animal Science 69: 1214-1222.

Birkelo, C. P. \& Lounsbery, J. 1992. Effect of straw and newspaper bedding on cold season feedlot performance in two housing systems. South Dakota Beef Reports, South Dakota State University, Brookings, USA: 42-45.

Christopherson, R.J. 1976. Effects of prolonged cold and the outdoor winter environment on apparent digestibility in sheep and cattle. Canadian Journal of Animal Science 56: 201-212.

Commission of the European Communities. 1982. Commission of the European Communities (Beef Carcass Classification) Regulations. Council Regulations 1358/80, 1208/81, 1202/82. Commission Regulations 2938/81, 563/82, 1557/82, Brussels.

Delfino, J.G. \& Mathison, G.W. 1991. Effects of cold environment and intake level on the energetic efficiency of feedlot steers. Journal of Animal Science 69: 4577-4587.

Dijkman, J.T. \& Lawrence, P.R. 1997. The energy expenditure of cattle and buffaloes walking and working in different soil conditions. Journal of Agricultural Science, Cambridge 128: 95-103.

Fraser, A.F. \& Broom, D.M. 1990. Farm Animal Behaviour and Welfare. $3^{\text {rd }}$ edition. Baillière Tindall, London, UK. 437 p.

Hänninen, L., Hepola, H., Rushen, J., De Passille, A.M., Pursiainen, P., Tuure, V.-M., Syrjälä-Qvist, L., Pyykkönen, M. \& Saloniemi, H. 2003. Resting behaviour, growth and diarrhoea incidence rate of young dairy calves housed individually or in groups in warm or cold buildings. Acta Agriculturae Scandinavica, Section A, Animal Sciences 53: 21-28.

Harmsen, H. E. \& Smits, A. C. 1981. Vleesstieren in geisoleerde en ongeisoleerde stallen. Proefstation voor de rundveehouderij, Report 82, Lelystad, Netherlands. $15 \mathrm{p}$.

Hepola, H., Hänninen, L., Pursiainen, P., Tuure, V.-M., Syrjälä-Qvist, L., Pyykkönen, M. \& Saloniemi, H. 2006. Feed intake and oral behaviour of dairy calves housed individually or in groups in warm or could buildings. Livestock Science 105: 94-104.

Hessle, A., Nadeau, E. \& Johnsson, S. 2007. Finishing of dairy steers having grazed semi-natural grasslands. Livestock Science 106: 19-27.
Hironaka, R. \& Peters, H.F. 1969. Energy requirements for wintering mature pregnant beef cows. Canadian Journal of Animal Science 49: 323-330.

Huuskonen, A., Khalili, H. \& Joki-Tokola, E. 2008. Need for protein supplementation in the diet of growing dairy bulls fed total mixed ration based on moderate digestible grass silage and barley. Agricultural and Food Science 17: 109-120.

Huuskonen, A., Khalili, H. \& Joki-Tokola, E. 2007a. Effects of three different concentrate proportions and rapeseed meal supplement to grass silage on animal performance of dairy-breed bulls with TMR feeding. Livestock Science 110: 154-165.

Huuskonen, A., Khalili, H. \& Joki-Tokola, E. 2007b. Effects of replacing different proportions of barley grain by barley fibre on performance of dairy bulls. Agricultural and Food Science 16: 232-244.

Kauppinen, R. 2000. Acclimatization of dairy calves to a cold and variable micro-climate. Doctoral dissertation, Institute of Applied Biotechnology, University of Kuopio, Finland. $105 \mathrm{p}$.

Keane, M.G., Drennan, M.J. \& Moloney, A.P. 2006. Comparison of supplementary concentrate levels with grass silage, separate or total mixed ration feeding, and duration of finishing in beef steers. Livestock Science 103: 169-180.

Kubisch, H.-M., Makarechian, M. \& Arthur, P.F. 1991. A note on the influence of climatic variables and age on the response of beef calves to different housing types. Animal Production 52: 400-403.

Lawrence, P.R. \& Stibbards, R.J. 1990. The energy costs of walking, carrying and pulling loads on flat surfaces by Brahman cattle and swamp buffalo. Animal Production 50: 29-39.

Lehtiniemi, T., Perälä, M. \& Holmström, S. 2001. Havaintoja ulkokasvatustiloilta. Oulu Rural Advisory Centre, Oulu, Finland. 16 p. (in Finnish).

LeRoy-Hahn, G.L. 1981. Housing and management to reduce climatic impacts on livestock. Journal of Animal Science 48: 103-112.

Levy, D., Holzer, Z. \& Volcani, R. 1970. Concrete slatted floors vs. bedding for fattening Israeli-Friesian bull calves. Journal of Animal Science 31: 816-820.

Lister, E.E., Jordan, W.A., Wauthy, J.M., Comeau, J.E. \& Pidgen, W.J. 1972. Effects of housing and type of forage on the response of pregnant beef cows to dietary energy intake in winter. Canadian Journal of Animal Science 52: 671-679.

Manninen, M., Sankari, S., Jauhiainen, J., Kivinen, T., Anttila, P. \& Soveri, T. 2008. Effects of outdoor winter housing and feeding level on performance and blood metabolites of suckler cows fed whole-crop barley silage. Livestock Science 115: 179-194.

Manninen, M., Sankari, S., Jauhiainen, J., Kivinen, T. \& Soveri, T. 2007. Insulated, uninsulated and outdoor housing for replacement beef heifers on restricted grass silage-based diet in a cold environment. Livestock Science 107: 113-125.

Manninen, M., Virkajärvi, P. \& Jauhiainen, L. 2005. Effect of whole-crop barley and oat silages on the performance of mature suckler cows and their progeny in outdoor winter feeding. Animal Feed Science and Technology 121: 227-242. 


\section{AGRICULTURAL AND FOOD SCIENCE}

Vol. 18 (2009): 16-26.

Mossberg, I., Lindell, L., Johnsson, S. \& Törnquist, M. 1993. Insulated and uninsulated housing systems for growing bulls fed grass silage ad libitum. Acta Agriculturae Scandinavica, Section A, Animal Sciences 43: 107-115.

Mossberg, I., Lindell, L., Johnsson, S., Törnquist, M. \& Engstrand, U. 1992. Two housing systems for intensively reared bulls slaughtered in two weight ranges. Acta Agriculturae Scandinavica, Section A, Animal Sciences 42: 167-176.

MTT. 2006. Rehutaulukot ja ruokintasuositukset (Feed tables and feeding recommendations) [online]. Agrifood Research Finland, Jokioinen. Published 14.2.2006, [cited 24.12.2007]. Available at: http://www.agronet.fi/rehutaulukot/. URN:NBN:fi-fe20041449.

Rawson, R.O., Dziuk, H.E., Good, A.L., Anderson, J.F., Bates, D.W. \& Ruth, G.R. 1989. Health and metabolic responses of young calves housed at -30 degrees ${ }^{\circ} \mathrm{C}$ to -8 degrees ${ }^{\circ} \mathrm{C}$. Canadian Journal of Veterinary Research 53: 268-274.

Redbo, I., Ehrlemark, A. \& Redbo-Torstensson, P. 2001. Behavioural responses to climatic demands of dairy heifers housed outdoors. Canadian Journal of Animal Science 81: 9-15.

Redbo, I., Mossberg, I., Ehrlemark, A. \& Ståhl-Högberg, M. 1996. Keeping growing cattle outside during winter: behaviour, production and climatic demand. Animal Science 62: 35-41.

Rintelen, von, P. \& Koller, G. 1966. Einfluss verschiedener Stallformen auf Gewichtszunahme und Futterver- brauch in der Jungbullenmast. Bayer. Landwirtschaft Jahr 43: 899-910.

Root, T. \& Huhtanen, P. 1998. Barley fibre and wet distillers' solubles in the diet of growing cattle. Agricultural and Food Science in Finland 7: 357-366.

Tuomisto, L., Ahola, L., Martiskainen, P., Kauppinen, R. \& Huuskonen, A. 2008. Comparison of time budgets of growing Hereford bulls in an uninsulated barn and in extensive forest paddocks. Livestock Science 118: 44-52.

Tuomisto, L., Huuskonen, A., Ahola, L. \& Kauppinen, R. 2009. Different housing systems for growing dairy bulls in Northern Finland - effects on performance, behaviour and immune status. Acta Agriculturae Scandinavica, Section A, Animal Sciences. Accepted for publication.

Uusi-Kämppä, J., Jauhiainen, L. \& Huuskonen, A. 2007. Phosphorus and nitrogen losses to surface waters from a forested feedlot for bulls in Finland. Soil Use and Management 23: Supplement 1: 82-91.

Webster, A. J. F. 1974. Heat loss from cattle with particular emphasis on the effects of cold. In: Monteith, J. L. and Mount, L. E. (eds.). Heat Loss from Animals and Man. Butterworth, London, UK. 448 p.

Westra, R. \& Christopherson, J. 1976. Effects of cold on digestibility, retention time of digesta, reticulum motility and thyroid hormone in sheep. Canadian Journal of Animal Science 56: 699-708. 
Huuskonen, A. et al. Performance of growing bulls under different housing conditions

\title{
SELOSTUS
}

\section{Hereford-sonnien tuotantotulokset lämpimässä parsinavetassa, eristämättömässä pihatossa ja ympärivuotisessa metsätarhakasvatuksessa Pohjois-Suomen olosuhteissa}

\author{
Arto Huuskonen, Leena Tuomisto, Erkki Joki-Tokola ja Risto Kauppinen \\ Maa- ja elintarviketalouden tutkimuskeskus ja Savonia-ammattikorkeakoulu
}

Tutkimuksen tarkoituksena oli selvittää kasvatusympäristön vaikutusta hereford-rotuisten lihanautojen kasvuun, rehun syöntiin sekä ruhon laatuun. Koe toteutettiin MTT:n Ruukin toimipisteessä, jonne koe-eläimet (30 sonnivasikkaa) hankittiin Tohmajärven emolehmänavetalta syksyllä 1999. Kasvatuskokeen alkaessa eläimet olivat keskimäärin 6,8 kuukauden ikäisiä ja painoivat $285 \mathrm{~kg}$. Kokeen alkaessa sonnit ryhmiteltiin elopainon perusteella kuuteen koeryhmään, joista kaksi (kummassakin 5 eläintä) sijoitettiin lämpimään parsinavettaan. Kaksi koeryhmää (5 eläintä/ryhmä) siirrettiin eristämättömään pihattoon, jossa ne sijoitettiin kahteen ryhmäkarsinaan. Kaksi viiden eläimen ryhmää sijoitettiin metsätarhaan vierekkäisiin aitauksiin. Parsinavetassa parsien etuosa oli kiinteää betonilattiaa ja takaosa metalliritilää. Parsissa ei käytetty kuiviketta. Eristämätön pihatto oli kolmiseinäinen rakennus, jossa karsina-alue muodostui lantakäytävästä ja kuivikepohjasta. Karsinassa oli tilaa 6,4 $\mathrm{m}^{2}$ eläintä kohti. Karsinan etuosassa sijaitsevalla ruokintapöydällä oli syöntitilaa $80 \mathrm{~cm}$ eläintä kohti. Kuivikepohjan päälle syntyvää makuualuetta kuivitettiin silputulla oljella tarpeen mukaan. Kuivikepohja tyhjennettiin säännöllisesti, samoin kuin lantakäytävälle kertynyt lanta. Metsätarha-alue oli nuorta sekametsää, joka jaettiin väliaidalla puoliksi kahdelle ryhmälle. Eläintä kohden tilaa oli 0,1 ha. Tarhaan rakennettiin pulpettikattoinen, kolmiseinäinen suojarakennus, joka puolitettiin väliseinän avulla kahden koeryhmän käyttöön. Rakennuksen takaosaan muotoiltiin hiekasta vinokuivikepohja, jonka päälle syntyvä makuuala oli kooltaan 3,2 $\mathrm{m}^{2}$ eläintä kohti. Makuualustaa käytettiin kestokuivikepohjan tavoin niin, että tarpeen mukaan makuupohjalle lisättiin silputtua olkea. Suojarakennuksen edessä sijaitsevan betonipohjaisen ruokinta-alueen etuosassa sijaitsevalla ruokintapöydällä oli syöntitilaa $100 \mathrm{~cm}$ eläintä kohti. Sonneja ruokittiin vapaasti seosrehulla, jonka kuiva-ainemäärästä $50 \%$ koostui esikuivatusta nurmisäilörehusta ja 50\% kuivana litistetystä ohrasta. Rehua jaettiin kaksi kertaa päivässä, ja ruokinnassa huolehdittiin myös eläinten kivennäisaineiden sekä vitamiinien tarpeesta. Puhdasta juomavettä eläimet saivat vapaasti. Koe päättyi lokakuussa 2000, jolloin sonnit olivat keskimäärin 18,3 kuukauden ikäisiä ja painoivat $772 \mathrm{~kg}$. Koko koeajalle laskettu päiväkasvu oli eristämättömässä pihatossa $7 \%$ suurempi kuin parsinavetassa (1436 vs. $1339 \mathrm{~g} \mathrm{~d}^{-1}, p<0,05$ ). Myös metsätarhakasvatuksessa sonnien päiväkasvu vaikutti olevan hieman parsinavettaa parempi (1414 vs. $1339 \mathrm{~g}$ $\left.\mathrm{d}^{-1}, p<0,1\right)$. Teuraspainon kasvu (nettokasvu) oli eristämättömässä pihatossa $8 \%$ suurempi kuin parsinavetassa (812 vs. $751 \mathrm{~g} \mathrm{~d}^{-1}, p<0,05$ ), mutta metsätarhan ja parsinavetan välillä ei ollut tilastollisesti merkitsevää eroa nettokasvussa. Ruhon lihakkuus oli metsätarhasonneilla $23 \%$ parempi kuin parsinavetan sonneilla (7,6 vs. 6,2 EUROP laatuluokitus, $p<0,05)$, mutta eristämättömän pihaton ja parsinavetan välille ei muodostunut eroa ruhojen lihakkuudessa. Ruohojen rasvaisuudessa ei ollut eroa kasvatusympäristöjen välillä. Rehun syönti ja energian saanti oli parsinavetan sonneilla selvästi pienempää kuin eristämättömässä pihatossa ja metsätarhassa kasvatetuilla sonneilla. Tulosten perusteella liharotuisia sonneja voidaan kasvattaa eristämättömissä rakennuksissa tai ulkotarhoissa Pohjois-Suomen ilmasto-olosuhteissa ilman, että eläinten tuotantotulokset heikkenevät. Tämä kuitenkin edellyttää, että eläimille tarjotaan vähintään tässä tutkimuksessa kuvatut kasvatusolosuhteet (säänsuoja, kuivitettu makuualue, puhdas juomavesi ja riittävästi rehua). Lisääntyneestä liikunnasta johtuen eläinten energian tarve on pihatto- ja ulkotarhakasvatuksessa suurempi kuin parressa kasvatetuilla sonneilla. 